\title{
MODEL PEMBINAAN PENINGKATAN KOMPETENSI PENILIK
}

\section{Melati Indri Hapsari}

\begin{abstract}
Non-formal education supervisors play an important role in providing and developing quality non-formal education. As their career development is based on their professional performance regulated in a credit system, many of the supervisors face hindrance to complete the requirement with the existing situation. This research introduces a model of supervisor's competence development resulted from a research conducted in five districts in Central Java involving a number of non-formal education supervisor. The model was developed on the bases of supervisor's competence mapping.
\end{abstract}

Key words: competence, supervisor, competence mapping

\section{Abstrak}

Penilik merupakan jabatan fungsional yang perkembangan kariernya ditentukan oleh angka kredit yang diperolehnya melalui bernagai jenis kegiatan yang relevan dengan tugas pokoknya. Akan tetapi, masih banyak penilik pendidikan nonformal mengalami kesultan dalam mengumpulkan angka kredit yang diperlukan untuk kenaikan pangka dan jabatannya. Penelitian yang dilakukan terhadap penilik-penilik pendidikan nonformal di lima kabupaten di Jawa Tengah selama empat bulan dalam tahun 2011 ini, berhasil menemukan suatu model pembinaan peningkatan kemampuan penilik nonformal yang dapat membantu mereka memperoleh angka kredit untuk pengembangan kariernya. Model yang dihasilkan didasarkan pada kompetensi penilik yang berhasil dipetakan

Kata-kata Kunci : kompetensi, penilik, pemetaan kompetensi

\section{PENDAHULUAN}

Surat Keputusan Menteri Pendayagunaan Aparatur Negara dan Reformasi Birokrasi Nomor 14 Tahun 2010 tanggal 6 Juli 2010 tentang Jabatan Fungsional Penilik dan Angka Kreditnya, merupakan dasar harapan Penilik yang selalu dicita-citakan. Hal ini akan dapat terwujud jika peraturan di atas dapat dilaksanakan oleh segenap Penilik dengan penuh profesional dan bijaksana. Salah satu faktor penentu keberhasilan pelaksanaan program-program Pendidikan Nonformal dan Informal (PNFI dulu PLS) di lapangan adalah profesionalisme dan kinerja optimal dari para Penilik PNFI.

Menurut Peraturan Menteri PAN dan RB nomor 14 tahun 2010 Penilik memiliki tugas utama melakukan kegiatan pengendalian mutu dan evaluasi dampak program PNFI. Untuk mendukung tugas pokok tersebut, Penilik berkewajiban melakukan berbagai kegiatan pengembangan profesi dalam rangka pengendalian mutu program PNFI.

Peningkatan karier seorang Penilik yang merupakan pejabat fungsional dilihat dari kenaikan pangkat dan jabatannya. Untuk kenaikan pangkat dan jabatannya tergantung dari pengumpulan angka kredit dari tugas pokoknya. Melihat kondisi tersebut perlu dilakukan kegiatan-kegiatan yang dapat meningkatkan kemampuan Penilik dalam melaksanakan tugas pokoknya sehingga dapat mengumpulkan angka kredit untuk kenaikan pangkat dan jabatannya.

Sudah beberapa rumusan digulirkan untuk peningkatan karir jabatan penilik di antaranya, peningkatan kualifikasi pendidikan bagi penilik yang belum S1, batas usia pensiun penilik 60 tahun, peningkatan tunjangan profesi, peningkatan kompetensi penilik melalui kegiatan pendidikan dan pelatihan, workshop, serta pembinaan.

Semua rumusan di atas belum sepenuhnya efektif untuk memotivasi Penilik untuk meningkatkan kompetensinya. Melihat kondisi tersebut maka perlu ada rumusan/formulasi/model yang sesuai untuk meningkatkan dan memotivasi pengembangan karier Penilik dengan meningkatkan kompetensi yang dimilikinya. P2PNFI Regional II Semarang sesuai dengan tugasnya merumuskan kebijakan teknis, pengkajian program, pengembangan model serta fasilitasi pengembangan sumber daya di bidang PNFI bermaksud menemukan/ merumuskan/ mengembangkan model pembinaan peningkatan kompetensi Penilik yang tepat dalam rangka peningkatan kinerja dan pengembangan karier Penilik. 
Untuk merumuskan dan memformulasikan model pembinaan peningkatan kompetensi Penilik perlu adanya suatu analisis pemetaan kompetensi Penilik sehingga model yang akan disusun dapat sesuai dengan kebutuhan Penilik.

Berdasar kajian latar belakang dan permasalahan seperti tersebut di atas dapat dirumuskan permasalahan utama dalam penelitian ini sebagai berikut.

1. Bagaimana kondisi umum dan gambaran umum kompetensi Penilik sesuai dengan Peraturan Menpan \& RB No. 14 Tahun 2010?

2. Apakah permasalahan yang dihadapi oleh Penilik dalam melaksanakan tugas pokoknya?

3. Bagaimana model dasar untuk melakukan pembinaan penilik dalam rangka meningkatkan kompetensi penilik?

Sebagai upaya untuk menjawab permasalahan tersebut di atas maka penelitian ini dilaksanakan untuk mencapai tujuan berikut.

1. Mendeskripsikan kondisi dan gambaran umum kompetensi Penilik sesuai dengan Peraturan Menpan \& RB No. 14 Tahun 2010.

2. Mendeskripsikan data dan informasi mengenai permasalahan yang dihadapi oleh Penilik dalam melaksanakan tugas pokoknya.

3. Menghasilkan model dasar untuk melakukan pembinaan penilik.

\section{KAJIAN PUSTAKA}

\section{Tinjauan Pembinaan}

Suatu organisasi akan berjalan dan bergerak maju, sangat tergantung pada upaya pembinaan atau perintah dari pemimpinnya. Pembinaan (directing) merupakan salah satu fungsi penting dalam manajemen. Menurut Fayol, seorang manajer harus mengetahui dan mampu sedemikian rupa mempertahankan sudut pandang dan kepercayaan karyawannya, agar dapat menerima perintah yang diberikan. Memberikan pembinaan secara tepat, tentang apa yang diharapkan dari pekerjaannya secara jelas merupakan kegiatan utama. Pembinaan harus mempunyai tujuan yang jelas, karena fungsi pembinaan berhubungan langsung dengan upaya dalam meningkatkan kinerja karyawan dan merealisasikan tujuan pelayanan. Menurut Urwick pembinaan adalah suatu "komando" untuk melihat bahwa kepentingan individu tidak mengganggu kepentingan umum, akan tetapi melindungi kepentingan umum dan akan menjamin masing-masing unit memiliki pemimpin yang kompeten dan energik. Keberhasilan kesatuan tersebut dalam manajemen modern disebut pembinaan atau directing (Handoko, 1997).
Fungsi pembinaan adalah untuk membuat agar karyawan melakukan tugas sesuai dengan apa yang diinginkan untuk mencapai tujuan organisasi, meningkatkan semangat korps. Roland dan Rowland menyatakan bahwa pembinaan dimulai dengan mempertahankan tindakan terhadap tujuan yang diinginkan yang saling terkait dengan kepemimpinan. Menurut Rowland, gaya kepemimpinan seorang manajer akan menjadi faktor utama dalam menjalankan fungsi pembinaan. Menurut Roland fungsi ini melibatkan gaya, kualitas dan kewenangan seorang pemimpin termasuk aktifitas lainnya seperti komunikasi, disiplin, dan motivasi. Bila fungsi perencanaan dan pengorganisasian lebih banyak menyangkut aspek-aspek abstrak manajemen, kegiatan pembinaan langsung menyangkut orang-orang yang terlibat dalam organisasi. Leading adalah istilah yang lebih tepat untuk fungsi pembinaan, karena pemimpin adalah orang yang menghasilkan sesuatu melalui kegiatan orang lain (stafnya) untuk mencapai tujuan organisasi. Diawali dengan menyelesaikan misi, tujuan dan sasaran departemen atau unit yang akan membina semua personil untuk memberikan pelayanan yang memuaskan pelanggan sehingga vitalitas organisasi dapat dipertahankan (Handoko, 1997).

Berikut ini beberapa kegiatan yang terkait dengan fungsi pembinaan (Handoko, 1997).

a. Membuat dan menggunakan rencana strategis dan taktis dengan menerima masukan dari staf untuk memudahkan perencanaan operasional.

b. Memudahkan pencapaian visi, misi, tujuan dan sasaran organisasi.

c. Memfasilitasi dan mempertahankan sumbersumber yang ada (SDM, alat/fasilitas).

d. Menjaga atau mempertahankan moral yang baik.

e. Memfasilitasi dan memberikan program pelatihan atau pendidikan berkelanjutan untuk mempertahankan kompetensi.

f. Menyediakan dan mempertahankan standar dalam bentuk kebijakan, prosedur, peraturan dan regulasi.

g. Mengkoordinasikan disiplin dalam semua aspek kegiatan.

h. Memudahkan dan mempertahankan hubungan interpersonal.

i. Memberikan kesempatan untuk konseling.

j. Membangun dan mempertahankan kepercayaan dan kerja tim.

k. Mengatasi atau mengelola konflik.

1. Mengorganisir sumber daya manusia potensial sebagai aset organisasi.

m. Mendelegasikan wewenang. 
Teori pengembangan manajemen hubungan antarmanusia, mendukung suatu pendekatan untuk pembinaan. Seorang manajer/pemimpin diharapkan memiliki pengetahuan dan keterampilan terkini agar dapat membina stafnya secara maksimal, dalam rangka menghasilkan kinerja yang berkualitas tinggi. Selain itu, seorang manajer harus memiliki kiat-kiat untuk membawa stafnya yang berbeda, dapat bekerja sama dalam mencapai tujuan organisasi. Untuk itu, seorang manajer harus lebih banyak mengetahui seluk beluk yang berhubungan dengan peraturan, kebijakan, prosedur atau standar, serta program atau perencanaan baru dalam organisasi. Kecerdikannya dalam memanfaatkan kemampuan memimpin sangat diperlukan. Pembinaan yang efektif akan meningkatkan kemampuan dan kemauan staf dalam menciptakan keselarasan antara tujuan organisasi dan tujuan staf. Sebagai fasilitator, manajer harus mampu membina stafnya agar dapat mengelola dirinya sendiri dalam kerja tim.

Tujuan pembinaan adalah sebagai berikut (Handoko, 1997).

a. Mengkoordinasikan kegiatan staf pelaksana, agar kegiatan yang beragam terkoordinasi pada satu arah atau satu tujuan.

b. Memeliharahubunganataukomunikasi interpesonal antara pimpinan dan staf. Melalui pembinaan yang diberikan atasan dapat menyalurkan ide-idenya sedemikian rupa sehingga staf dapat memahami dengan tepat apa yang diharapkan dari dirinya.

c. Mendidik atau memberikan tambahan pengetahuan/ pengalaman bagi staf.

d. Pengawasan atau pengendalian, serta pembinaan dimaksudkan agar tidak terjadi penyimpangan dan diarahkan pada tujuan organisasi.

\section{Tinjauan tentang Penilik}

Jabatan fungsional penilik adalah jabatan fungsional yang mempunyai ruang lingkup, tugas, tanggung jawab, dan wewenang untuk melakukan kegiatan pengendalian mutu dan evaluasi dampak program pendidikan anak usia dini (PAUD), pendidikan kesetaraan dan keaksaraan, serta kursus pada jalur Pendidikan Nonformal dan Informal (PNFI) sesuai dengan peraturan perundang-undangan yang diduduki oleh pegawai negeri sipil. Penilik adalah tenaga kependidikan dengan tugas utama melakukan kegiatan pengendalian mutu dan evaluasi dampak program PAUD, pendidikan kesetaraan dan keaksaraan, serta kursus pada jalur PNFI. Tugas pokok Penilik adalah melaksanakan kegiatan pengendalian mutu dan evaluasi dampak program PNFI. Jenis Penilik berdasarkan bidang tugasnya terdiri atas
Penilik PAUD, Penilik pendidikan kesetaraan dan keaksaraan, serta Penilik kursus.

Instansi Pembina jabatan fungsional Penilik adalah Kementerian Pendidikan Nasional. Instansi

Pembina mempunyai tugas pembinaan antara lain:

a. menyusun petunjuk teknis pelaksanaan jabatan fungsional penilik,

b. menyusun pedoman formasi jabatan fungsional penilik,

c. menetapkan standar kompetensi jabatan fungsional penilik,

d. menyusun pedoman uji kompetensi jabatan fungsional penilik,

e. mengusulkan tunjangan jabatan fungsional penilik,

f. melakukan sosialisasi jabatan fungsional penilik serta petunjuk pelaksanaannya,

g. menyusun kurikulum pendidikan dan pelatihan fungsional penilik,

h. menyelenggarakan pendidikan dan pelatihan fungsional penilik,

i. mengembangkan sistem informasi jabatan fungsional penilik,

j. memfasilitasi pelaksanaan tugas pokok jabatan fungsional penilik,

k. memfasilitasi pembentukan dan pembinaan organisasi profesi penilik,

1. memfasilitasi penyusunan dan penetapan etika profesi dan kode etik penilik,

m. melakukan bimbingan teknis kompetensi dan profesionalitas jabatan fungsional penilik, dan

n. melakukan monitoring dan evaluasi pelaksanaan jabatan fungsional penilik.

Unsur dan sub unsur kegiatan penilik yang dapat dinilai angka kreditnya terdiri atas hal-hal berikut.

a. Pendidikan, meliputi pendidikan sekolah dan memperoleh ijazah/gelar; dan pendidikan dan pelatihan (diklat) fungsional Penilik serta memperoleh Surat Tanda Tamat Pendidikan dan Pelatihan (STTPP) atau sertifikat.

b. Kegiatan pengendalian mutu program PNFI, meliputi perencanaan program pengendalian mutu PNFI, pelaksanaan pemantauan program PNFI, pelaksanaan penilaian program $\mathrm{PNFI}$, pelaksanaan pembimbingan dan pembinaan kepada pendidik dan tenaga kependidikan pada satuan PNFI, dan penyusunan laporan hasil pengendalian mutu PNFI.

c. Kegiatan evaluasi dampak program PNFI meliputi penyusunan rancangan/desain evaluasi dampak program PNFI, penyusunan instrumen 
evaluasi dampak program PNFI, pelaksanaan dan penyusunan laporan hasil evaluasi dampak program PNFI, dan presentasi hasil evaluasi dampak program PNFI.

d. Kegiatan pengembangan profesi, meliputi pembuatan karya tulis ilmiah (KTI) dan/atau penelitian di bidang PNFI, penerjemahan/ penyaduran buku dan bahan lainnya di bidang PNFI, dan pembuatan standar buku pedoman/ petunjuk pelaksanaan/ petunjuk teknis di bidang pengendalian mutu PNFI, serta menjadi juara dalam lomba karya ilmiah.

e. Kegiatan penunjang pelaksanaan tugas penilik, meliputi pengajaran/pelatihan di bidang pengendalian mutu dan evaluasi dampak program PNFI, keikutsertaan dalam seminar/lokakarya di bidang PNFI, partisipasi aktif dalam penerbitan buku/majalah di bidang PNFI, studi banding di bidang pengendalian mutu program PNFI, keanggotaan dalam tim penilai jabatan fungsional penilik, perolehan penghargaan/tanda jasa/ tanda kehormatan/satya lancana karya satya, keanggotaan dalam organisasi profesi jabatan fungsional Penilik, dan perolehan ijazah/gelar kesarjanaan lainnya.

\section{METODOLOGI PENELITIAN}

Penelitian ini menggunakan pendekatan penelitian kuantitatif dan kualitatif. Pendekatan ini dipergunakan karena ada dua variabel berbeda yang ingin diteliti. Jenis penelitian ini termasuk studi eksplorasi. Studi eksplorasi ini diperlukan agar diperoleh kejelasan yang komprehensif mengenai fokus pengkajian baik dari segi permasalahan, tujuan, konsep, maupun cara-cara yang dapat ditempuh dalam menjawab permasalahan pengembangan. Tipe studi eksplorasi yang digunakan adalah experience survey. Experience survey adalah studi dengan menanyakan pengetahuan individu tentang masalah-masalah yang terkait dengan penelitian.

Jenis data dalam penelitian ini adalah data kuantitatif untuk menemukan dan mengenali gambaran umum kompetensi penilik dengan menggunakan kuesioner/angket. Sedangkan data kualitatif untuk menemukan dan mengenali berbagai data serta informasi mengenai permasalahan yang dihadapi oleh Penilik dalam melaksanakan tugas pokoknya dengan menggunakan pedoman wawancara.

Sampel penelitian sebanyak 60 responden (orang) untuk data kuantitatif sedangkan untuk data kualitatif sebanyak 20 orang. Penelitian ini dilaksanakan pada bulan April - Juli 2011. Tempat penelitian dilaksanakan di lima Kabupaten/Kota yaitu Kabupaten Karanganyar, Kabupaten Wonogiri, Kabupaten Kudus, Kabupaten Kendal, Kabupaten Wonosobo. Alasan memilih lima kabupaten tersebut untuk mewakili Propinsi Jawa Tengah karena lima kabupaten tersebut mempunyai Penilik dalam jumlah yang cukup banyak.

Data yang diperoleh dalam penelitian ini dianalisis secara deskripsi kuantitatif untuk data yang diperoleh dari kuesioner dan deskripsi kualitatif untuk data yang diperoleh dari wawancara. Data kuantitatif dianalisis dengan statistik deskripsi menggunakan rerata tiap kompetensi.. Sedangkan untuk data kualitatif akan dianalisis menggunakan tahap-tahap sebagai berikut (Miles \& Huberman, 1992).

\section{HASIL DAN PEMBAHASAN}

\section{Temuan Data}

\section{Gambaran Kondisi Umum Penilik \\ a. Umur}

Gambaran distribusi frekuensi penilik berdasarkan umur dapat dilihat pada tabel $1 \mathrm{di}$ bawah ini.

Tabel 1. Distribusi Frekuensi Penilik Berdasarkan Umur

\begin{tabular}{|c|c|c|c|}
\hline No & Umur (tahun) & Jumlah & Persentase \\
\hline 1. & $20-30$ & 1 & $1,6 \%$ \\
\hline 2. & $31-40$ & 7 & $11,6 \%$ \\
\hline 3. & $41-50$ & 26 & $43,3 \%$ \\
\hline 4. & $51-60$ & 26 & $43,3 \%$ \\
\hline \multicolumn{2}{|c|}{ Jumlah } & 60 & $100 \%$ \\
\hline
\end{tabular}

Dari data di atas dapat dikemukakan bahwa usia penilik, sebagaian besar adalah usia dewasa/ matang yaitu pada rentang 41 - 60 tahun sebanyak orang $(86,6 \%)$. Pada usia tersebut, penilik seharusnya sudah memiliki kompetensi yang sesuai dengan tugas pokok dan fungsinya. Mereka memiliki etos kerja yang tinggi untuk menunjukkan eksistensinya sebagai penilik yang professional.

b. Golongan

Deskripsi distribusi frekuensi penilik berdasarkan golongan dapat dilihat pada tabel 2 berikut ini.

Tabel 2. Distribusi Frekuensi Penilik Berdasarkan Golongan

\begin{tabular}{|c|c|c|c|}
\hline No & Golongan & Jumlah & Persentase \\
\hline 1. & III/A & 12 & $20 \%$ \\
\hline 2. & III/B & 1 & $1,7 \%$ \\
\hline 3. & III/C & 7 & $11,7 \%$ \\
\hline
\end{tabular}




\begin{tabular}{|c|c|c|c|}
\hline No & Golongan & Jumlah & Persentase \\
\hline 4. & III/D & 11 & $18,3 \%$ \\
\hline 5. & IV/A & 28 & $46,6 \%$ \\
\hline 6. & IV/B & 1 & $1,7 \%$ \\
\hline \multicolumn{2}{|c|}{ Jumlah } & 60 & $100 \%$ \\
\hline
\end{tabular}

Data pada tabel 2 menunjukkan bahwa sebagai besar penilik mempunyai golongan IV/a sebanyak 28 orang $(46,6 \%)$. Banyaknya Penilik yang berada pada golongan IV/a karena untuk naik ke golongan berikutnya diperlukan syarat pengembangan profesi pada saat pengajuan angka kredit. Padahal penilik dalam mengalami kesulitan dalam penulisan pengembangan profesi.

Tabel 3. Distribusi Frekuensi Penilik Berdasarkan Pendidikan

\begin{tabular}{|c|c|c|c|}
\hline No & Umur (tahun) & Jumlah & Persentase \\
\hline 1. & D1 & 2 & $3,3 \%$ \\
\hline 2. & D2 & 6 & $10 \%$ \\
\hline 3. & D3 & - & - \\
\hline 4. & S1 & 45 & $75 \%$ \\
\hline 5. & S2 & 7 & $11,7 \%$ \\
\hline & Jumlah & 60 & 100 \\
\hline
\end{tabular}

Dari tabel 3 diketahui bahwa sebagian besar Penilik mempunyai pendidikan sarjana sebanyak 45 orang $(75 \%)$. Melihat kondisi tersebut maka sebagian Penilik telah memiliki kualifikasi yang sesuai dengan Permenpan dan RB no 14 tahun 2010.

\section{Gambaran Umum Kompetensi Penilik}

a. Kompetensi Personal

Kompetensi personal Penilik berdasarkan masing-masing kabupaten dapat dilihat pada tabel 4

Tabel 4. Nilai Kompetensi Personal Penilik Berdasarkan Kabupaten

\begin{tabular}{|c|c|c|c|}
\hline No & Lokasi & Skor & Persentase \\
\hline 1. & Kabupaten Kendal & 13,59 & $91 \%$ \\
\hline 2. & Kabupaten Kudus & 14,40 & $96 \%$ \\
\hline 3. & Kabupaten Wonosobo & 13,6 & $91 \%$ \\
\hline 4. & Kabupaten Karanganyar & 13,27 & $88 \%$ \\
\hline 5. & Kabupaten wonogiri & 12,79 & $85 \%$ \\
\hline \multicolumn{2}{|r|}{ Rata-Rata } & 13,53 & $90,2 \%$ \\
\hline
\end{tabular}

Dari data di atas dengan rata-rata skor adalah 13,53 (90,2 \%) menunjukkan bahwa kompetensi personal Penilik sudah memadai. Skor maksimal kompetensi personal adalah 15. Kemampuan personal pada tabel di atas mencerminkan kepribadian yang mantap, stabil, dewasa, arif, dan berwibawa, dapat menjadi teladan bagi masyarakat serta berakhlak mulia.

b. Kompetensi Sosial

Kompetensi personal Penilik berdasarkan masing-masing kabupaten dapat dilihat pada tabel 5.

Tabel 5. Nilai Kompetensi Sosial Penilik Berdasarkan Kabupaten

\begin{tabular}{|c|c|c|c|}
\hline No & Lokasi & Skor & Persentase \\
\hline 1. & Kabupaten Kendal & 13,2 & $87 \%$ \\
\hline 2. & Kabupaten Kudus & 13,00 & $87 \%$ \\
\hline 3. & Kabupaten Wonosobo & 13,00 & $87 \%$ \\
\hline 4. & Kabupaten Karanganyar & 13,13 & $88 \%$ \\
\hline 5. & Kabupaten Wonogiri & 12,71 & $85 \%$ \\
\hline & Rata-Rata & 13,042 & $86,8 \%$ \\
\hline
\end{tabular}

Dari tabel 5 diketahui bahwa kompetensi sosial penilik mempunyai rerata skor yang bagus yaitu 13,042 (86,8 \%). Kompetensi sosial berkenaan dengan kemampuan Penilik sebagai bagian dari masyarakat untuk berkomunikasi dan bergaul secara efektif dengan masyarakat sekitar. Pada tabel di atas menunjukkan bahwa kompetensi ini memiliki indikator esensial yang sudah baik antara lain:

1) menguasai karakteristik sosial, ekonomi dan budaya masyarakat setempat;

2) bekerja sama dengan berbagai pihak dalam melaksanakan tupoksi sebagai Penilik satuan pendidikan nonformal;

3) berperan serta dalam kegiatan organisasi profesi Penilik dan organisasi profesi lainnya;

4) peka terhadap berbagai masalah yang terjadi pada masyarakat setempat; dan

5) menguasai masalah sosial kemasyarakatan dan cara pemecahannya.

c. Kompetensi Teknis

Kompetensi teknis Penilik dibagi menjadi tiga tugas yaitu pengendalian mutu program PNFI, evaluasi dampak program PNFI, dan pengembangan profesi untuk menunjang kedua tugas pokok tersebut.

1) Pengendalian mutu program PNFI

Kompetensi teknis penilik tentang pengendalian mutu program PNFI berdasarkan masing-masing kabupaten dapat dilihat pada tabel 6.

Tabel 6. Nilai Pengendalian Mutu Program PNFI

\begin{tabular}{|c|l|c|c|}
\hline No & \multicolumn{1}{|c|}{ Lokasi } & Skor & Persentase \\
\hline 1. & Kabupaten Kendal & 29,27 & $65 \%$ \\
\hline 2. & Kabupaten Kudus & 38,20 & $85 \%$ \\
\hline 3. & Kabupaten Wonosobo & 37,00 & $82 \%$ \\
\hline 4. & Kabupaten Karanganyar & 35,40 & $79 \%$ \\
\hline
\end{tabular}

Perspektif Ilmu Pendidikan - Vol. 24 Th. XV Oktober 2011 


\begin{tabular}{|c|c|c|c|}
\hline No & Lokasi & Skor & Persentase \\
\hline 5. & Kabupaten Wonogiri & 32,86 & $70 \%$ \\
\hline \multicolumn{2}{|c|}{ Rata-Rata } & 34,546 & $76,2 \%$ \\
\hline
\end{tabular}

Kompetensi penilik pada pengendalian mutu program, penilik harus mampu memotret mutu satuan pendidikan nonformal dan informal, serta mampu melakukan dan meningkatkan pengendalian mutu, yaitu meningkatkan perencanaan program pengendalian mutu PNFI, pelaksanaan pemantauan program PNFI, pelaksanaan penilaian program PNFI, pelaksanaan pembimbingan dan pembinaan kepada pendidik dan tenaga kependidikan pada satuan PNFI, dan penyusunan laporan hasil pengendalian mutu PNFI. Data di atas menunjukkan bahwa kompetensi Penilik di bidang pengendalian mutu program PNFI rata-rata sebesar 34,546 (76,2\%).

2) Evaluasi dampak program PNFI

Kompetensi teknis penilik tentang evaluasi dampak program PNFI berdasarkan masing-masing kabupaten dapat dilihat pada tabel 7.

Tabel 7. Nilai Evaluasi Dampak Program PNFI

\begin{tabular}{|c|c|c|c|}
\hline No & Lokasi & Skor & Persentase \\
\hline 1. & Kabupaten Kendal & 9,65 & $64 \%$ \\
\hline 2. & Kabupaten Kudus & 11,20 & $75 \%$ \\
\hline 3. & Kabupaten Wonosobo & 11,20 & $75 \%$ \\
\hline 4. & Kabupaten Karanganyar & 10,33 & $69 \%$ \\
\hline 5. & Kabupaten Wonogiri & 9,71 & $65 \%$ \\
\hline \multicolumn{2}{|r|}{ Rata-Rata } & 10,418 & $69 \%$ \\
\hline
\end{tabular}

Data di atas menunjukkan bahwa kompetensi evaluasi dampak program PNFI penguasaan oleh Penilik adalah 10,418 (69\%). Evaluasi dampak adalah kompetensi atau penguasaan penilaian, memantau, menilai, membina, serta mengevaluasi pembelajaran, pendidik dan tenaga kependidikan PNFI. Secara rinci masing-masing elemen kompetensi tersebut memiliki subkompetensi dan indikator esensial yang cukup.

3) Pengembangan profesi

Kompetensi teknis Penilik tentang pengembangan profesi berdasarkan masing-masing kabupaten dapat dilihat pada tabel 8 .

Tabel 8. Nilai Pengembangan Profesi

\begin{tabular}{|c|c|c|c|}
\hline No & Lokasi & Skor & Persentase \\
\hline 1. & Kabupaten Kendal & 7,29 & $60 \%$ \\
\hline 2. & Kabupaten Kudus & 8,6 & $72 \%$ \\
\hline 3. & Kabupaten Wonosobo & 8,00 & $67 \%$ \\
\hline 4. & Kabupaten Karanganyar & 6,47 & $54 \%$ \\
\hline 5. & Kabupaten Wonogiri & 6,43 & $54 \%$ \\
\hline \multicolumn{2}{|r|}{ Rata-Rata } & 7,35 & $61,4 \%$ \\
\hline
\end{tabular}

Pengembangan profesi adalah kompetensi yang berkenaan dengan penguasaan ilmu pengetahuan, prosedur penelitian, dan terampil menyusun penelitian. Dari data di atas menunjukkan bahwa rerata kompetensi pengembangan profesi yang dikuasai oleh penilik sebesar 7,35 (61,4\%). Kompetensi ini merupakan kompetensi teknis penilik yang mempunyai rerata paling kecil diantara kompetensi teknis yang lain. Sehingga perlu mendapatkan perhatian dalam rangka peningkatannya apalagi kompetensi ini berhubungan dengan penyusunan karya tulis/ilmiah yang merupakan syarat agar penilik dapat naik pangkatnya menjadi IV/b.

4) Kompetensi budaya

Kompetensi personal penilik berdasarkan masing-masing kabupaten dapat dilihat pada tabel 9.

Tabel 9. Nilai Kompetensi Budaya Penilik Berdasarkan Kabupaten

\begin{tabular}{|c|c|c|c|}
\hline No & Lokasi & Skor & Persentase \\
\hline 1. & Kabupaten Kendal & 9,65 & $64 \%$ \\
\hline 2. & Kabupaten Kudus & 11,20 & $75 \%$ \\
\hline 3. & Kabupaten Wonosobo & 11,20 & $75 \%$ \\
\hline 4. & Kabupaten Karanganyar & 10,33 & $69 \%$ \\
\hline 5. & Kabupaten Wonogiri & 9,71 & $65 \%$ \\
\hline \multicolumn{2}{|r|}{ Rata-Rata } & 10,418 & $69 \%$ \\
\hline
\end{tabular}

Data di atas menunjukkan bahwa kompetensi budaya kerja pendidik sangat baik karena rata-rata sebesar 13,786 (91, 6 \%). Skor tertinggi dari kompetensi budaya adalah 15. Dengan demikian kompetensi budaya Penilik perlu dipertahankan.

\section{Informasi Mengenai Permasalahan yang Dihadapi oleh Penilik dalam Melaksanakan Tugas Pokoknya}

Data dan informasi yang diperoleh mengenai permasalahan yang dihadapi oleh penilik dalam melaksanakan tugas pokoknya antara lain.

a. Tugas pokok penilik sesuai dengan Peraturan Menpan \& RB pada umumnya belum dipahami dan dilaksanakan oleh Penilik.

Hal tersebut diketahui dari hasil wawancara dengan Penilik dari Kabupaten Kendal, Bapak Rokiban.

"Untuk tugas pokok sesuai dengan Permen yang baru belum pernah dilaksanakan baru sosialisasi."

Pendapat tersebut juga didukung pernyataan dari salah satu Penilik di Kabupaten Kudus, Bapak Gufron.

“Tugas Penilik yang baru belum jelas sehingga sampai sekarang belum bisa dipahami oleh Penilik. 
Untuk mengajukan angka kredit malas karena belum ada kejelasan.....".

Melihat kondisi tersebut perlu diterapkan strategi yang tepat agar Penilik di lapangan paham dengan peraturan pemerintah yang terbaru yang berhubungan dengan tugas pokok Penilik. Strategi yang dapat dilakukan antara lain dengan sosialisasi, pembinaan.

b. Pemahaman Penilik mengenai teknis programprogram PNFI masih kurang, sehingga menjadi hambatan dalam rangka pengendalian mutu.

Ada kesenjangan pengetahuan mengenai teknis program, antara Penilik dengan penyelenggara program PNFI di lapangan. Bahkan umumnya penyelenggara program/pengelola lebih paham standar program PNFI dibandingkan Penilik sebagai pihak yang mengendalikan mutu program PNFI di lapangan.

Hal tersebut sesuai dengan hasil wawancara dengan Penilik dari Kabupaten Kudus, Bapak Gufron.

“..... Sementara yang mendesak adalah kegiatan untuk pembekalan awal tentang pengetahuan tentang PAUD, Kesetaraan dan sebagainya agar Penilik yang bukan dari Dikmas tidak blank dalam menjalankan tugas."

Kondisi tersebut juga didukung pernyataan dari Penilik Kabupaten Wonogiri, Bapak Ngadiyo.

“......Dalam melaksanakan tugas, kami sering terkendala kalau ada pertanyaan dari pelaksana program tentang hal-hal teknis program PNFI, misalnya tentang kurikulum. Kami menyadari pemahaman kami tentang teknis program masih kurang sehingga hal ini menjadi hambatan dalam pelaksanaan tugas kami dalam rangka pengendalian mutu program PNFI."

c. Pengembangan profesi terutama bagi Penilik memerlukan pembinaan terutama karena pemahaman tentang penulisan karya ilmiah sangat kurang.

Kondisi tersebut hampir dirasakan oleh semua Penilik di lima kabupaten. Hal tersebut dapat dilihat dari petikan beberapa hasil wawancara dengan Penilik di lima kabupaten.

Hasil wawancara dengan Kepala Bidang PNF Dinas Pendidikan Kabupaten Karanganyar, Bapak Drs. Harjono, M.Pd.

“Dalam hal pengembangan profesi, sampai saat ini Penilik, hampir semua di Karanganya masih bingung, dan pihak dinas akan mencoba mencari satu pendamping dalam pengembangan profesi ini."

Hasil wawancara dengan Penilik Kabupaten
Kendal, Bapak Rokiban.

“Di Kendal ini juga terkendala kemarin kami ingin mengadakan koordinasi dengan UNNES atau P2PNFI berkaitan dengan pengembangan profesi itu kan kita mentok. Rencananya teman-teman Penilik itu mau mengundang di Boja atau dimana ya demi karier kita cuma waktunya kapan tinggal ditentukan."

Hasil wawancara dengan Penilik Kabupaten Kudus, Bapak Gufron.

"Beberapa sudah menyusun karya ilmiah namun belum bisa dibilang baik, karena tidak mengetahui tata cara penulisannya. Saya kemaren juga sudah nulis untuk ikut dalam Jambore. Saya pakai juga untuk PAK, tapi banyak Penilik IVa yang mentok karena malas menyusun PAK. Dulu ada teman dapat undangan mengikuti pelatihan di P2PNFI tentang itu tapi materi yang diberikan malah lebih banyak tentang PTK. Padahal yang dibutuhkan rekan Penilik kan penelitian yang lebih luas atau umum. Usulan saya mohon adanya bimbingan penulisan karya ilmiah terutama yang sudah IV a yang dijembatani P2."

d. Dinas kabupaten/kota belum melaksanakan pembinaan yang terjadwal berkaitan dengan peningkatan kompetensi Penilik untuk mendukung tugas pokok Penilik sehari-hari.

Kondisi tersebut diketahui dari beberapa hasil wawancara dengan responden. Salah satunya pendapat dari Penilik Kabupaten Kendal, Bapak Rokiban.

"Ada setiap bulan sekali kami yang mengundang dari IPI, tempatnya berpindah-pindah biasanya tanggal satu. Yang datang biasanya Kelapa Dinas atau Kabid atau Kasi ada pembinaan. Pembinaan selama ini dilakukan ketika kami yang mengundang, dinas belum ada kegiatan khusus untuk pembinaan Penilik. Tapi ini sudah mulai bangun dengan ini adanya sembilan TLD yang masuk ke Penilik sudah mulai bangkit eksistensi Penilik."

Pendapat tersebut didukung oleh pernyataan dari Penilik Kabupaten Wonogiri, Bapak Ngadiyo.

"Selama ini kami para Penilik belum secara definitif mendapatkan pembinaan dari (Dinas Pendidikan). Yang selama ini ada atau berjalan adalah rapat kerja tiap tiga bulan sekali antara semua Penilik dengan bidang PNFI. Dalam rapat ini, kami mendapatkan pembekalan tentang berbagai kebijakan terbaru dalam bidang PNFI, pembekalan tentang pelaksanaan program/petunjuk teknis sekaligus sharing kalau ada permasalahan."

Tugas pembinaan seyogya dilakukan oleh instansi pembina Penilik, dalam hal ini adalah Direktorat Pembinaan Pendidik dan Tenaga 
Kependidikan Kementerian Pendidikan Nasional. Namun karena Kementerian Pendidikan mempunyai perpanjangan tangan di masing-masing daerah, maka ada beberapa tugas dari instansi pembina yang dapat dilakukan oleh Dinas Pendidikan Kabupaten/Kota. Tugas instansi pembina yang dapat dilakukan oleh Dinas Pendidikan Kabupaten/Kota antara lain:

1) melakukan sosialisasi jabatan fungsional penilik serta petunjuk pelaksanaannya,

2) menyelenggarakan pendidikan dan pelatihan fungsional penilik,

3) mengembangkan sistem informasi jabatan fungsional penilik,

4) memfasilitasi pelaksanaan tugas pokok jabatan fungsional penilik,

5) memfasilitasi pembentukan dan pembinaan organisasi profesi penilik,

6) melakukan bimbingan teknis kompetensi dan profesionalitas jabatan fungsional penilik, dan
7) melakukan monitoring dan evaluasi pelaksanaan jabatan fungsional penilik.

Kalau pun ada pembinaan dari Dinas Pendidikan, maka materi pembinaan yang dilakukan oleh dinas pendidikan masih berkisar tentang kebijakan dan permasalahan yang terjadi pada program PNFI. Hal tersebut sesuai dengan pendapat Penilik Kabupaten Kendal, Bapak Rokiban.

“Motivasi, program-program, tidak teknis tugas Penilik."

Hasil wawancara dengan Penilik Kabupaten Wonosobo, Bapak Sugiyanto, S.Ag.

"Karena yang datang koordinator IPI bentuk pembinaannya sebatas perkembangan Penilik atau informasi terbaru dan saling silahturahmi saja."

\section{Pembahasan}

Pembahasan merupakan alur kerangka pikir dalam rangka menemukan model pembinaan yang tepat dari data temuan penelitian.

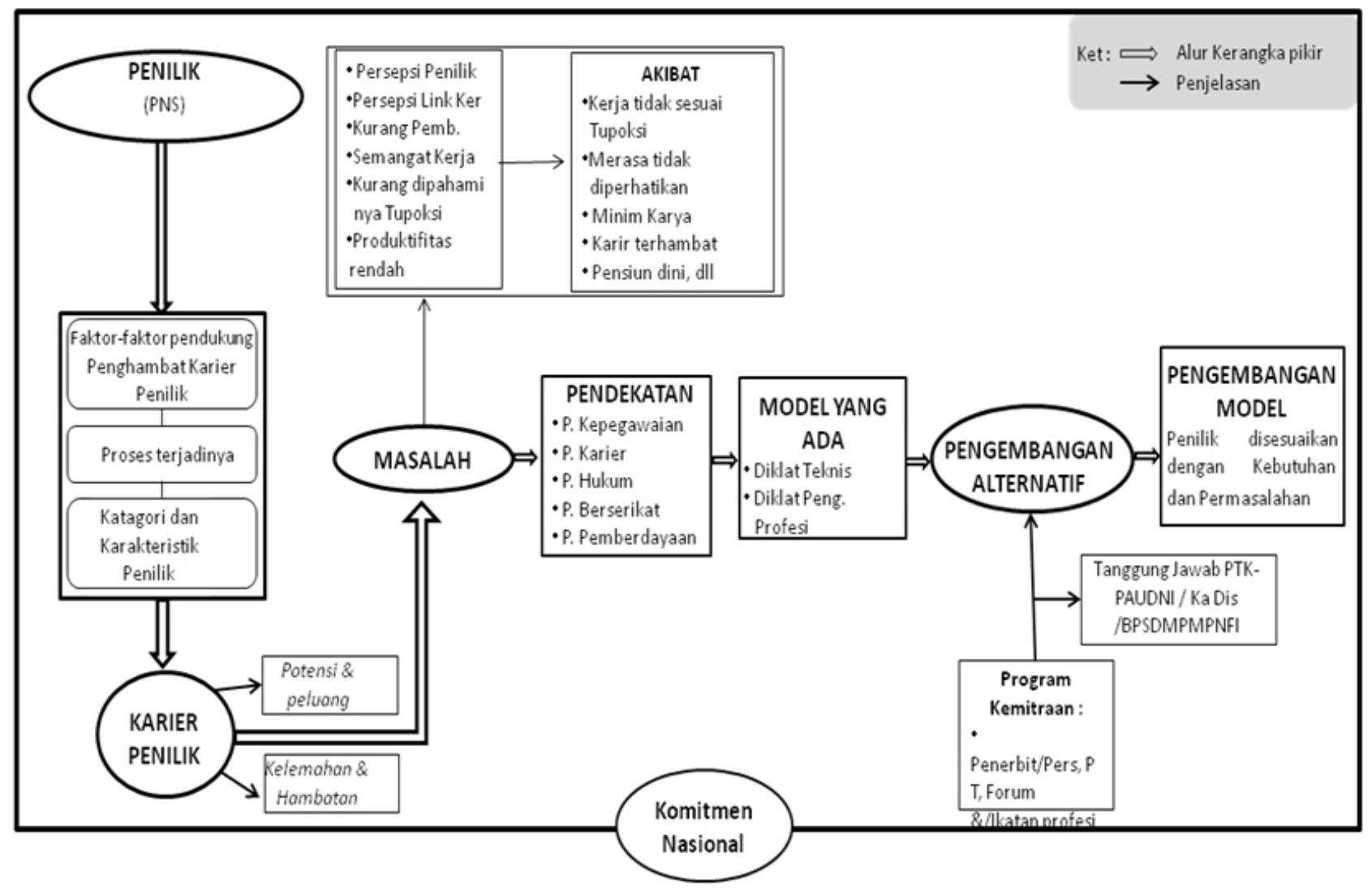

Gambar 1. Pengembangan Model Pembinaan Kompetensi Penilik Pendidikan Nonformal dan Informal

Pengembangan Model Pembinaan Kompetensi Penilik Pendidikan Nonformal dan Informal sebagaimana kerangkanya digambarkan di atas penjelasannya sebagai berikut.

a. Tahap Awal. Perlunya memahami substansi penilik sebelum masuk pada inti permasalahan yang mana Penilik berstatus sebagai pegawai negeri sipil (PNS). Tujuan memahami susbtansi ini adalah agar terjadi keseragaman persepsi terhadap keberadaannya sebagai dasar dalam mencari solusi dari permasalahan yang ada. Keberadaan penilik ditinjau dari statusnya sebagai PNS diperlukan pemahaman dari beberapa regulasi yang ada. Beberapa regulasi yang perlu dipahami antara 
lain:

1) pengaturan aparat pemerintah dalam era otonomi daerah,

2) Undang-Undang tentang Sistem Pendidikan Nasional,

3) Peraturan Pemerintah RI tentang Standar Pendidikan Nasional, dan

4) Peraturan Menteri Pendayagunaan Aparatur Pemerintah dan reformasi Birokrasi yang berlaku bagi Penilik.

b. Tahap Kedua. Pada tahap ini pengembang mulai terfokus pada permasalahan yang ada berkisar tentang fakta yang ada di lapangan terkait dengan tugas-tugas Penilik. Secara sederhana dapat digambarkan sebagai berikut.

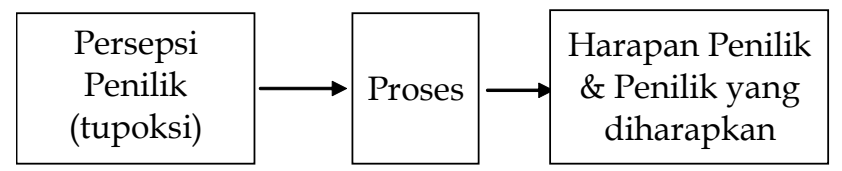

Gambar 2. Tahap kedua

Mulai dari persepsi mengenai tugas pokok dan fungsi penilik terhadap tugasnya, hingga menjadi penilik yang diharapkan dan harapan mereka terhadap karier mereka, maka ada aspek-aspek yang perlu diketahui sebagai berikut.

1) Faktor-faktor pendukung dan penghambat karier Penilik

2) Proses terbentuknya karier Penilik

3) Kategori dan karakteristik Penilik PNFI

Tahap yang ketiga, yaitu mengetahui kategori dan karakteristik penilik saat ini sangat penting. Melalui pemahaman ini pengembang dapat mengidentifikasi sekaligus mengklasifikasi penilik PNFI dalam mencari solusi bagi permasalahan yang ada berkenaan dengan pendekatan yang perlu diambil dalam pembinaan karier penilik. Begitu pula pada faktor-faktor pendukung dan penghambat penilik serta proses yang harus dilalui penilik dalam berkarier. Melalui pemahaman ketiga aspek tersebut diharapkan dapat ditemukan solusi baik secara preventif maupun kuratif.

c. Tahap Ketiga. Hal terpenting sekaligus dapat mempermudah dalam upaya mencari solusi atas permasalahan yang dihadapi penilik PNFI untuk dilakukan pembinaan selama ini adalah dengan mengetahui seberapa besar potensi yang ada pada diri penilik untuk menjalankan tugas-tugasnya, serta sejauh mana peluang yang dimiliki penilik untuk menjalankan tupoksinya sebagai upaya keluar dari permasalahan yang ada. Sedangkan faktor-faktor kelemahan dan hambatan dapat dijadikan patokan bagi pengembang akan adanya batas atau rambu-rambu yang perlu diperhatikan saat masalah ditangani.

d. Tahap Keempat. Dalam upaya pembinaan penilik, pendekatan yang selama ini diterapkan antara lain.

1) Pendekatan Kepegawaian.

2) Pendekatan Karier.

3) Pendekatan Hukum.

4) Pendekatan Berserikat.

Kesimpulan yang bisa diambil dari pendekatan-pendekatan diatas adalah.

1) Konsep pendekatan yang selama ini ada cukup memberikan kenyamanan kerja bagi Penilik, seperti.

a) Jaminan kenaikan pangkat yang lebih cepat daripada kenaikan secara reguler,

b) Usia Pensiun hingga 60 tahun,

c) Adanya jaminan Harlindung atas profesinya, dan

d) Kebebasan untuk berserikat dalam rangka penggalangan kekuatan dan penyamaan persepsi.

2) Pada pendekatan pemberdayaan diperlukan hal terpenting yang perlu diperhatikan: (1) apakah selama ini penilik telah diberdayakan sesuai dengan tupoksinya, dan (2) apakah pembinaan selama ini telah dilakukan dalam rangka pembinaan kariernya.

e. Tahap Kelima. Model pembinaan yang selama ini ada baru terbatas pada hal-hal berikut.

1) Diklat teknis terkait dengan tupoksi penilik dan masih menggunakan acuan Kepmenpan yang lama, dimana penilik tugas utamanya melakukan penilikan program PNFI.

2) Diklat pengembangan profesi. Bentuk diklat yang ada selama ini adalah berupa diklat terkait dengan penyusunan karya ilmiah tentang kepenilikan.

3) Pembinaan tugas rutin oleh atasan. Pembinaan ini memiliki kelemahan disaat lingkungan kerja yang seharusnya membina penilik tidak memahami tupoksi penilik. Akibatnya penilik melaksanakan tugas yang tidak sesuai tupoksi. Hal ini kedepan sangat merugikan karier penilik.

f. Tahap Keenam. Dari berbagai masalah yang ada, didapatkan pola penanganan dengan berbagai pendekatan dan melalui program-program diklat yang telah ada. Namun hal tersebut nampaknya belum memberikan solusi yang efektif. Untuk itu, perlu diciptakan suatu alternatif program/ 
sistem pembinaan bagi penilik sehingga mereka dapat diberdayakan dan bekerja sesuai dengan tupoksinya sehingga menjadi manusia yang produktif.

g. Tahap ketujuh. Pengembangan model pembinaan kompetensi Penilik PNFI diharapkan dapat menjadi solusi atas permasalahan yang ada berdasarkan harapan dan kebutuhan bersama baik penilik sebagai pelaku kegiatan maupun birokrat setempat yang berkepentingan untuk meningkatkan mutu/kualitas program pendidikan di wilayah kerjanya.

\section{PENUTUP}

Kesimpulan yang dapat diperoleh dari penelitian ini adalah sebagai berikut.

1. Kondisi umum penilik menunjukan usia yang bervariasi tetapi kebanyakan penilik berada pada usia 40-60 tahun, dengan pendidikan rata-rata sarjana dengan golongan III/a sampai IV/b;

2. Latar belakang penilik beragam, baik dari segi pendidikan maupun waktu lamanya pengabdian;

3. Pembinaan yang fokus pada pengembangan profesi dan tupoksi penilik belum dilaksanakan. Selama ini baru rapat kerja tentang program dan permasalahan yang dihadapi oleh penilik;

4. Mengharapkan pertemuan penilik, menjadi pertemuan rutin untuk pembinaan sehingga bisa memberdayakan tugas penilik secara maksimal; dan

5. Penguasaan kompetensi oleh penilik sudah menunjukan penguasaan yang baik, namun di bidang kompetensi teknis, terutama pada evaluasi program PNF dan pengembangan profesi masih perlu ditingkatkan.
Rekomendasi yang dapat diberikan adalah perlu adanya model pembinaan terhadap penilik terutama untuk peningkatan kompetensinya. Model pembinaan kompetensi penilik mempunyai fungsi sebagai berikut.

1. Berfungsi sebagai wadah perjuangan dalam meningkatkan kemampuan profesi dan kesejahteraan penilik,

2. Kerja sama dalam menyelenggarakan pelatihanpelatihan untuk meningkatkan kualitas sumber daya penilik,

3. Mengadakan bimbingan dalam rangka mempertinggi kesadaran penilik akan profesinya untuk meningkatkan mutu keahlian, kemampuan, pengabdian, prestasi dan kerja sama,

4. Memberikan solusi terbaik bagi permasalahan yang timbul dalam pelaksanaan tugas kepenilikan, dan

5. Saling memberikan informasi, pengetahuan dan pengalaman antar penilik dalam pelaksanaan kepenilikan pendidikan nonformal.

\section{DAFTAR PUSTAKA}

Handoko, T.hani. 1997. Manajemen. Yogyakarta: $\mathrm{BPFE}$

Miles, M.B \& Huberman, A.M.1992. Qualitativ Data Analisis. Berverly Hill: Sage Publication Inc

Peraturan Menteri Negara Pendayagunaan Aparatur Negara dan Reformasi Birokrasi Nomor 14 Tahun 2010 tentang Jabatan Fungsional Penilik dan Angka Kreditnya

\section{KETERANGAN PENULIS}

Melati Indri Hapsari, saat ini aktif sebagai Pamong Belajar P2PNFI Regional II Semarang 